\title{
Spermatozoa Revival with Addition of Diluted Dextrose Saline in African Catfish (Clarias gariepinus Burchell 1822)
}

\author{
*Idahor K. O. ${ }^{1}$, Hamza J. ${ }^{1}$, Okunsebor S. A. ${ }^{2}$, Osayande U. D. ${ }^{3}$, Isah N. ${ }^{2}$, Osaiyuwu O. H. ${ }^{3}$ and \\ Sokunbi O. A. ${ }^{3}$ \\ ${ }^{1}$ Department of Animal Science, Nasarawa State University, Keffi, Shabu-Lafia Campus, Lafia, 950101, Nigeria \\ ${ }^{2}$ Department of Aquaculture and Fisheries Management, Nasarawa State University, Keffi, Shabu-Lafia \\ Campus, Lafia, 950101, Nigeria. \\ ${ }^{3}$ Animal Science Department, Faculty of Agriculture and Forestry, University of Ibadan, Ibadan, Nigeria. \\ *Corresponding Author: Idahor K. O., Department of Animal Science, Nasarawa State University, Keffi, \\ Shabu-Lafia Campus, Lafia, 950101, Nigeria.
}

\begin{abstract}
African catfish (Clarias gariepinus) production in captivity is still at the subsistent level in Nigeria largely due to its inability to reproduce naturally in captivity. In artificial breeding, rigorous operations which require high technical-know-how involving sacrifice of the male brood stock often result in colossal wastages. Thus, this study was aimed at using diluted dextrose saline to resuscitate African catfish spermatozoa in order to reduce the number of male brood stock to be sacrificed at a time as well as minimize milt wastages.

The harvested milt was evaluated microscopically for alive or dead spermatozoa cells, active or sluggish spermatozoa cells as well as spermatozoa cells concentration every quarter hour, after adding the diluted dextrose saline. Results indicated that alive sperm cells value was as high as $79.0 \%$ in control $\left(T_{1}\right)$ at 0 minute compared to $4.00 \%$ recorded at 15 minutes later and there were absolutely no more alive sperm cells at 30 minutes and beyond. Whereas, addition of diluted dextrose saline resuscitated the sperm cells in $T_{2}$ by up to $50.0 \%$ motility at 1 hour and thereafter, all the sperm cells were no longer motile. Out of these resuscitated sperm cells, $52.5 \%$ were actively motile and $47.5 \%$ were sluggish.

Consequently, diluted dextrose saline could be used as a cryoprotectant in the preservation and storage of fish milt for short term duration in artificial breeding. This technique may be practicable in hatchery operations in order to boost African catfish production in Nigeria.
\end{abstract}

Keywords: Brood stock, milt collection, preservation, spawning

\section{INTRODUCTION}

Catfish (Clarias gariepinus) belongs to the family of Claridae which is naturally carnivorous, bottom dweller, nocturnal and it is widely distributed across the African Aquatic regions. It has been described as hardy with ability to breathe and survive outside water for some time using accessory organs and it adapts to prevailing environmental conditions even with poor water quality [1]. Clarias gariepinus could also be described as an omnivore which basically feeds on aquatic and terrestrial insects, fish, mollusk, higher plant debris and fruits [2, 3]. According to [4], diets compositions intended for Clarias species should change with age such that diptera of small sizes and zooplankton predominates the ration. Little wonders $C$. gariepinus is believed to be the most suitable species for aquaculture in Africa because of its high growth rate attaining $1 \mathrm{~kg}$ at about 6 months, resistant to handling stress, easy to propagate in captivity and it commands very high commercial value both at homes and in eateries in Nigeria. More importantly, it is typically non aggressive but could defend itself from predators by stalking non-visual primary sense organs especially barbels and other tactile organs [5, 6]. It is called "Ehęnbevbarię" among the Benin tribe of The Great Benin Kingdom in Nigeria, who highly relish it especially at ceremonies and cultural events. Therefore, C. gariepinus could be produced in Nigeria to augment animal protein needs of the citizenry.

At the moment, fish production in Nigeria is still at the subsistent level thus, cannot meet the demands of the populace. This was believed to be due to scarcity of good brood stock hence, the suggestion of 
cryopreservation of genetic resources of available brood stock for all-year-round supply of fish seed [7]. On the other hand, it could be due to the refusal of C. gariepinus to breed in captive, even when a gravid female is kept with a mature male, no matter how long, with all the required management principles strictly observed, there will be no spawning in captive.

In some experimental conditions however, natural scenario was simulated and mimicked yet, there were no appreciable natural spawning. While appropriate hormones were administered in females to enhance oocytes and eggs stripping in captive catfish, the males were reported to be sacrificed in order to obtain the milt for artificial spawning. Meanwhile, in C. gariepinus reared in captivity at $25.0^{\circ} \mathrm{C}$ and 12 hours photoperiod, gametogenesis was reported to be continuous in sexually mature males $[1,8,9,10]$. The act of sacrificing the male catfish, may lead to scarcity of brood stock because there would be wastages in each round of breeding operations [11]. This probably prompted the use of syringe and needle to obtain milt from life catfish but reported seldom possibility [12]. Since cryopreservation technique requires appropriate extender, diluents, very low refrigeration temperature, follow by careful thawing and stringent expertise, it may not be feasible in most farmstead operations in Nigeria. Consequently, this study was aimed at investigating the possibility of using diluted dextrose saline to preserve and store catfish milt in order to reduce wastages of male brood stock during artificial breeding.

\section{Materials ANd Methods}

\section{Experimental design and fish welfare}

A total of four male C. gariepinus brood stock, weighing about $0.60 \mathrm{~kg}$ were bought from a sales outlet in Bukan Sidi, Lafia. They were transported in plastic container filled with clean water to Animal Science Laboratory, Faculty of Agriculture, Nasarawa State University Keffi, Shabu-Lafia Campus. The fish were allotted to two treatments in a completely randomised design based on body weight such that each treatment had two replicates. The treatments were designated as $T_{1}$ (control: without diluted dextrose saline) and $\mathrm{T}_{2}$ (with diluted dextrose saline). The male fish were only used as a source of milt collection that were either diluted with or without dextrose saline used in this study.

\section{Dextrose saline dilution}

A sachet of dextrose saline (Glaxoß) and a litter of distilled water were procured from a reputable pharmaceutical store in Lafia. A syringe was used in taken $1 \mathrm{ml}$ of dextrose saline and $2 \mathrm{ml}$ of distilled water into a test tube and was properly mixed by shaking to prepare $50.0 \%$ dextrose saline used in the experiment. The dilution became necessary in order to avoid spermatozoa death observed by [13], who reported that $100 \%$ dextrose saline was lethal to catfish spermatozoa.

\section{Milt quality evaluation}

Two drops of the diluted dextrose saline was taken with a micropipette into a test tube containing a drop of milt and mixed carefully by turning the test tube. A drop of the diluted dextrose saline and milt mixture was then taken with a microscope slide, covered with a slip and viewed in a microscope (Olympus Microscope ${ }^{\circledR}$ Tokyo, Japan) at 10x and 40x magnifications, to determine alive or dead spermatozoa cells, active or sluggish spermatozoa cells as well as spermatozoa cells concentration as described $[14,15]$. This procedure was repeated differently at every quarter hour (15 minutes) to collect data except, the milt volume and sperm cells concentration that were determined only at 0 minute.

\section{Data collection and analysis}

On arrival, the fish were transferred into an open bowl containing clean water where each fish was picked and weighed using a table scale (Five Goats ${ }^{\circledR}$ ) to obtain body weight. The standard body length was taken from the mouth to the caudal fin base, while the total body length was taken from the mouth to the end of the caudal fin using measuring tape (Butterfly®). Papilla length, left and right fin length were measured using measuring tape (Butterfly®). Thereafter, all the fish were sacrificed, the abdomen was carefully dissected, thermometer probe was placed on the testes immediately to obtain testes temperature and another thermometer was hung on the wall to obtain room temperature. The left and right testes were collected carefully and the length was taken using measuring tape (Butterfly®). The testes were incised carefully using surgical blade and the milt was gently squeezed out, pooled and a known volume $(0.50 \mathrm{ml})$ was measured each for treatments 1 and 2 respectively. The 
milt $\mathrm{pH}$ was determined with a $\mathrm{pH}$ strip differently whenever it was time to evaluate the milt quality. Data collected were subjected to analysis of variance based on statistical procedure of [16] and the mean values were separated according to Duncan Multiple Range Test of the same software package.

\section{Results}

Table 1 shows the body linear measurements of African catfish used in the study. The mean values of all the parameters measured were not significantly different $(P>0.05)$, except the right fin length value which was statistically longer $(P<0.05)$ in the fish in $\mathrm{T}_{2}(12.0 \mathrm{~cm})$ compared to $11.0 \mathrm{~cm}$ recorded in $\mathrm{T}_{1}$. Meanwhile, the body weight value ranged from 0.63 to $0.64 \mathrm{~kg}$, standard body length (42.1 to $42.2 \mathrm{~cm})$, total body length $(48.0$ to $48.1 \mathrm{~cm})$ and the testes length varied between 4.71 and $4.77 \mathrm{~cm}$.

Table 1. Body linear measurements of African catfish (C. gariepinus)

\begin{tabular}{|l|l|l|}
\hline \multirow{2}{*}{ Parameters } & \multicolumn{2}{|c|}{ Treatments $( \pm$ SEM $)$} \\
\cline { 2 - 3 } & $\mathrm{T}_{1}$ & $\mathrm{~T}_{2}$ \\
\hline Body weight $(\mathrm{kg})$ & $0.64 \pm 0.005$ & $0.63 \pm 0.02$ \\
\hline Standard body length $(\mathrm{cm})$ & $42.2 \pm 0.30$ & $42.1 \pm 0.10$ \\
\hline Total body length $(\mathrm{cm})$ & $48.1 \pm 0.10$ & $48.0 \pm 0.25$ \\
\hline Papilla length $(\mathrm{cm})$ & $1.82 \pm 0.015$ & $1.82 \pm 0.005$ \\
\hline Left fin length $(\mathrm{cm})$ & $12.5 \pm 0.50$ & $12.5 \pm 0.50$ \\
\hline Right fin length $(\mathrm{cm})$ & $11.0 \pm 0.00^{\mathrm{b}}$ & $12.0 \pm 0.00^{\mathrm{a}}$ \\
\hline Room Temperature $\left({ }^{0} \mathrm{C}\right)$ & $36.3 \pm 0.05$ & $36.4 \pm 0.025$ \\
\hline Testis temperature $\left({ }^{\circ} \mathrm{C}\right)$ & $26.0 \pm 0.00$ & $26.0 \pm 0.00$ \\
\hline Left testis length $(\mathrm{cm})$ & $4.73 \pm 0.025$ & $4.77 \pm 0.03$ \\
\hline Right testis length $(\mathrm{cm})$ & $4.75 \pm 0.045$ & $4.71 \pm 0.005$ \\
\hline
\end{tabular}

a, b: Means with different letters on the same row are significantly different at $\mathrm{P}<0.05 ; \pm \mathrm{SEM}$ : Plus or minus standard error of means; $\mathrm{T}_{1}$ (control: without diluted dextrose saline); $\mathrm{T}_{2}$ (with diluted dextrose saline).

The effect of time of addition of diluted dextrose saline on C. gariepinus milt is presented in Table 2 . There were statistical differences $(P<0.05)$ in the mean values of all the parameters measured across the treatments. However, there were no significant differences $(P>0.05)$ in alive sperm cells $(75.0-$ $79.0 \%)$, dead sperm cells $(21.0-25.0 \%)$, active motile sperm cells $(70.0-85.0 \%)$ and sluggish motile sperm cells $(15.0-30.0 \%)$ at 0 minutes treatment. Similarly, values of all the parameters at 1:15hour treatment did not differ statistically $(P>0.05)$ except, the sperm cells concentration which was higher $\left(566 \times 10^{6}\right)$ in $\mathrm{T}_{1}$ compared to $567 \times 10^{6}$ recorded in $\mathrm{T}_{2}$. Milt $\mathrm{pH}$ value varied from 7.60 at 30minutes treatment to as high as 8.90 at 0 and 45 minutes treatments. It was observed that alive sperm cells value was very high (79\%) in control at 0minute which was drastically reduced to $4 \%$ at 15 minutes treatment and without any alive sperm cell activity (absolutely $0.00 \%$ ) thereafter. At 30minutes and beyond, all the sperm cells (absolutely 100\%) were observed dead in the control treatment $\left(\mathrm{T}_{1}\right)$ whereas in $\mathrm{T}_{2}$, addition of diluted dextrose saline resuscitated the sperm cells up to $50.0 \%$ in 1 hour. Out of these resuscitated sperm cells in $\mathrm{T}_{2}, 52.5 \%$ were actively motile and $47.5 \%$ were sluggish.

Table 2. Effect of time of addition of diluted dextrose saline on African catfish (C. gariepinus) milt quality

\begin{tabular}{|c|c|c|c|c|c|c|c|c|c|c|c|c|}
\hline \multirow[b]{3}{*}{ Parameters } & \multicolumn{12}{|c|}{ Treatments $( \pm$ SEM $)$} \\
\hline & \multicolumn{2}{|c|}{0 minute* } & \multicolumn{2}{|c|}{15 minutes* } & \multicolumn{2}{|c|}{30 minutes* } & \multicolumn{2}{|c|}{45 minutes* } & \multicolumn{2}{|c|}{1 hour* } & \multicolumn{2}{|c|}{ 1:15 hour* } \\
\hline & $\mathrm{T}_{1}$ & $\mathrm{~T}_{2}$ & $\mathrm{~T}_{1}$ & $\mathrm{~T}_{2}$ & $\mathrm{~T}_{1}$ & $\mathrm{~T}_{2}$ & $\mathrm{~T}_{1}$ & $\mathrm{~T}_{2}$ & $\mathrm{~T}_{1}$ & $\mathrm{~T}_{2}$ & $\mathrm{~T}_{1}$ & $\mathrm{~T}_{2}$ \\
\hline$\phi \mathrm{MV}(\mathrm{ml})$ & $0.5 \pm 0.00$ & $0.5 \pm 0.00$ & $0.5 \pm 0.00$ & $0.5 \pm 0.00$ & $0.5 \pm 0.00$ & $0.5 \pm 0.00$ & $0.5 \pm 0.00$ & $0.5 \pm 0.00$ & $0.5 \pm 0.00$ & $0.5 \pm 0.00$ & $0.5 \pm 0.00$ & $0.5 \pm 0.00$ \\
\hline Milt pH & $7.8 \pm 0.2^{\mathrm{b}}$ & $8.9 \pm 0.0^{\mathrm{a}}$ & $7.9 \pm 0.1^{\mathrm{b}}$ & $8.8 \pm 0.0^{\mathrm{a}}$ & $7.6 \pm 0.4$ & $8.8 \pm 0.0$ & $8.9 \pm 0.0^{\mathrm{a}}$ & $8.8 \pm 0.0^{\mathrm{b}}$ & $8.8 \pm 0.0$ & $8.8 \pm 0.0$ & $8.8 \pm 0.0$ & $8.8 \pm 0.0$ \\
\hline $\operatorname{ASC}(\%)$ & $79 \pm 1.0$ & $75 \pm 5.0$ & $4.0 \pm 1.0^{\mathrm{b}}$ & $71.5 \pm 6.5^{\mathrm{a}}$ & $0.0 \pm 0.0^{\mathrm{b}}$ & $69.0 \pm 9.0^{\mathrm{a}}$ & $0.0 \pm 0.0^{\mathrm{b}}$ & $58.5 \pm 1.55^{\mathrm{a}}$ & $0.0 \pm 0.0^{\mathrm{b}}$ & $50 \pm 0.0^{\mathrm{a}}$ & $0.0 \pm 0.0$ & $0.0 \pm 0.0$ \\
\hline$\overline{\mathrm{DSC}}(\%)$ & $21 \pm 1.0$ & $25 \pm 5.0$ & $96 \pm 1.0^{\mathrm{a}}$ & $28.5 \pm 6.5^{\mathrm{b}}$ & $100 \pm 0.0^{\mathrm{a}}$ & $31.0 \pm 9.0^{\mathrm{b}}$ & $100 \pm 0.0^{\mathrm{a}}$ & $41.5 \pm 1.5^{\mathrm{b}}$ & $100 \pm 0.0^{\mathrm{a}}$ & $50 \pm 0.0^{\mathrm{b}}$ & $100 \pm 0.0$ & $100 \pm 0.0$ \\
\hline $\operatorname{AMSC}(\%)$ & $70 \pm 5.0$ & $85 \pm 0.0$ & $6.0 \pm 4.0^{\mathrm{b}}$ & $80.0 \pm 0.0^{\mathrm{a}}$ & $0.0 \pm 0.0^{\mathrm{b}}$ & $75 \pm 5.0^{\mathrm{a}}$ & $0.0 \pm 0.0^{\mathrm{b}}$ & $62.5 \pm 7.5^{\mathrm{a}}$ & $0.0 \pm 0.0^{\mathrm{b}}$ & $52.5 \pm 2.5^{\mathrm{a}}$ & $0.0 \pm 0.0$ & $0.0 \pm 0.0$ \\
\hline SMSC (\%) & $30 \pm 5.0$ & $15 \pm 0.0$ & $94 \pm 4.0^{\mathrm{a}}$ & $20.0 \pm 0.0^{\mathrm{b}}$ & $0.0 \pm 0.0$ & $25 \pm 5.0$ & $0.0 \pm 0.0^{\mathrm{b}}$ & $37.5 \pm 7.5^{\mathrm{a}}$ & $0.0 \pm 0.0^{\mathrm{b}}$ & $47.5 \pm 2.5^{\mathrm{a}}$ & $0.0 \pm 0.0$ & $0.0 \pm 0.0$ \\
\hline $\begin{array}{l}\text { SCC } \\
\left(\mathrm{x} 10^{6}\right)\end{array}$ & $566 \pm 5.0^{\mathrm{a}}$ & $567 \pm 0.0^{b}$ & $566 \pm 5.0^{\mathrm{a}}$ & $567 \pm 0.0^{b}$ & $566 \pm 5.0^{\mathrm{a}}$ & $567 \pm 0.0^{b}$ & $566 \pm 5.0^{\mathrm{a}}$ & $567 \pm 0.0^{b}$ & $566 \pm 5.0^{\mathrm{a}}$ & $567 \pm 0.0^{b}$ & $566 \pm 5.0^{\mathrm{a}}$ & $567 \pm 0.0^{b}$ \\
\hline
\end{tabular}

${ }^{\phi}$ Milt volume and sperm cells concentration were determined only at 0 minute; ${ }^{*}$ Mean values comparison was per time treatment only and not across treatments; $a, b$ : Means with different letters on the same row at the same time per treatment are significantly different at $P<0.05 ; \pm S E M$ : Plus or minus standard error of means; $T_{l}$ (control: without diluted dextrose saline); $T_{2}$ (with diluted dextrose saline); MV: Milt volume; ASC: Alive sperm cells; DSC: Dead sperm cells; AMSC: Active motile sperm cells; SMSC: Sluggish motile sperm cell; SCC: Sperm cells concentration.

\section{DISCUSSION}

The standard body length values of $48.5-50.1 \mathrm{~cm}$, total body length of $55.4-56.3 \mathrm{~cm}$ and body weight value of about $0.6 \mathrm{~kg}$ were similar to the criterion for selecting mature catfish of about 4 to 12 
months old [8]. The papilla and fin length values were similar to $1.31-1.55 \mathrm{~cm}$ and $6.26-7.07 \mathrm{~cm}$ respectively as reported [12] in sexually matured African catfish. Thus, the results probably indicated that the experimental fish were sexually matured. The milt $\mathrm{pH}$ value was higher than 6.2 reported [17] in mature and healthy $C$. gariepinus. The disparity could be possibly due to strain differences and experimental conditions. The sperm cells motility value was similar to a range of $70.0-90.0 \%$ observed by [18] and much more than $15 \%$ given by [17] in African catfish. The observed variation could be probably due to the kind of treatments involved and probably the time interval of evaluation. The sperm cells concentration value was higher than $5.16 \times 10^{8}$ reported in healthy and mature $C$. gariepinus [17] thus, the experimental fish were probably physiologically sound.

It was observed that the milt quality was not influenced by the addition of diluted dextrose saline at 0minute but at 15minutes, the milt quality was tremendously improved. This trend was observed up to $1 \mathrm{hr}$, when the sperm cells were observed to be resuscitated by the inclusion of the diluted dextrose saline. This observation contradicted the report [19] that carp sperm cell dilution and/or washing in various media (seminal fluid, saline solution) did not improve preservation. However, the findings was similar to the report of [20] that physiological saline, Ringer or saline as cryoprotectant retained sperm cell motility. Thus, dextrose saline could be used as a cryoprotectant to preserve fish milt for a short term probably without refrigeration or long term with refrigeration, during artificial breeding in other to boost catfish production in captivity.

This technique may be relevant in instances where harvested milt were not used up immediately as described by $[21,22]$ and needed to be preserved either in a short term or long term with or without refrigeration. Regrettably, up to this moment, catfish cannot reproduce naturally in captive according to [23] hence, the need to adopt any practicable and safe artificial measures to spawn, hatch and brood the young ones in order to boost productivity.

\section{CONCLUSION}

The body linear values of the experimental fish apparently indicated their sexual maturity and the milt $\mathrm{pH}$, alive sperm cells motility as well as the sperm cells concentration values, seemingly showed that the fish were physiologically healthy. The overall milt quality evaluated was similar to the standards given in mature and healthy fish. It was observed that the addition of diluted dextrose saline evidently resuscitated the sperm cells for up to an hour.

Therefore, it might be a practicable technique to preserve and store catfish milt for a short term during artificial breeding operation. This may minimize the number of males that will be sacrificed in captive catfish production. Meanwhile, further in depth investigation is required to evaluate the fertilizing ability of such preserved and stored catfish milt for elucidation.

\section{REFERENCES}

[1] de Graaf G. J., Galemoni F. and Banzoussi B., The artificial reproduction and fingerling production of the African catfish Clarias gariepinus (Burchell 1822) in protected and unprotected ponds. Aqua Res, 26: 233242. (1995).

[2] Gupta S. K. and Gupta P. C., General and Applied Ichthyology (Fish and Fisheries), S. Chand and Company Ltd, 7361, Ram Nager, New Delhi, 110055, 1130. (2006).

[3] Bruton M. N., The food and feeding behaviour of Clarias gariepinus (Pisces, Claridae) in lake Sibaya, South Africa, with its emphasis on its role as a predator of cichlids. Trans. Zool. Soc. London, 35: 47-114. (1979).

[4] Groenewald A. A. V. J., Observations on the food habits of Clarias gariepinus Burchell, the South African freshwater Barbel (Pisces: Claridae) in Transvaal. Hydrobiol., 23: 267-273. (1964).

[5] Bruton M. N., Alternative life-history strategies of catfishes. In: Legendre M, Proteau J P, editors. The Biology and Culture of Catfishes. Aquat. Living Res., Paris. 9 Hors Series, pp 35-41, (1996).

[6] Hetch T., Oellermann L. and Verheust L., Perspectives and Clariid catfish culture in Africa. In: Legendre M., Proteau JP, editors. The Biology and Culture of Catfishes. Aquatic Living Resources. Paris, 9, Hors Series, pp. 206 (1996).

[7] Omitogun O. G., Oyeleye O. O., Betiku C. O., Ojiokpota C., Aladele S. E. and Sarumi M. B. Potentials of short-term cryopreserved sperm of the giant African catfish, Clarias gariepinus (Burchell, 1822) for aquaculture in Nigeria. Proc. $31^{\text {st }}$ Ann. Conf. of Genetic Society of Nigeria, Moor Plantation, Ibadan, Nigeria, pp.141 (2006). 
[8] FAO., Handbook on the artificial reproduction and pond rearing of the African catfish (Clarias gariepinus) in sub-Saharan Africa. Food and Agricultural Organization, Fisheries Technical Paper 362, Rome. (1996)

[9] Tonguthai, K, China S, Limsuwan C, Somsiri, T, Chanratchakool P, Kanchanakhan et. al., Handbook of hybrid catfish: Husbandry and health. Aquatic Animal Health Research Institute, Department of Fisheries, Kasetsart University Campus, Jatujak, Bangkok 10900, Thailand, pp.37 (1993).

[10] Viveen W. J. A. R., Richter C. J. J., Van Oordt P. G. W. J., Jansen, J. A. L. and Huisman E. A., Practical Manual for the Culture of the African Catfish (C. gariepinus) 2500 EB, The Hague, The Netherland, pp. 94 (1996).

[11] Steyn G. J., The fertilizing capacity of cryopreserved sharp tooth catfish, Clarias gariepinus sperm. Aquaculture, 6:187-193. (1987).

[12] Idahor K. O., Microscopic observation of spermatozoa in milt collected with syringe without sacrificing the male African Catfish (Clarias anguillaris B. 1911). Int'1 J Fish Aquat Stud, 2(1): 88-91, ISSN: 2347-5129 www.fisheriesjournal.com. (2014).

[13] Okunsebor S. A., Imgbian T. D. and Manomi B. B., Effects of different dilutions of saline on some sperm parameters and their influences on fertilization, hatchability and survival rate of hatchlings of catfish (Clarias gariepinus). Proc 29th Ann Conf FISON, pp.98. (2014).

[14] Egbunike G. N. A toast for spermatozoa: One half the story of mammalian life. An Inaugural Lecture Series, University of Ibadan, Ibadan Nigeria, pp.58 (1995).

[15] SIGMA., Cell counting and cell viability. Saint Louis, MO 63178 USA, p. 1634, (1994).

[16] SAS., Statistical Analysis System, User's Guide. Statistical. Version 9.1 e4d. SAS. Inst. Inc. Cary. N.C. USA. (2012).

[17] Ayoola S. O., Relationships of chemical composition, quantity of milt to fertility and hatchability of Clarias gariepinus (Burchell, 1822). Afri. J. Food Agric. Nutr. Dev. 9(4):1031-1045. (2009).

[18] Mansour N., Lahnsteiner F. and Patzner R. A., The spermatozoon of the African catfish: fine structure, motility, viability and its behaviour in seminal vesicle secretion. J. Fish Biol, 60: 545-560. doi:10.1006/jfbi.2002.1869. (2002).

[19] Saad A., Billard R., Theron M. C. and Hollebecq M. G., Short-term preservation of carp (Cyprinus carpio) semen. Aquaculture, 71(1-2): 133-150. (1988).

[20] Muchlisin Z. A., Hashim R. and Chong A. S. C., Preliminary study on the cryopreservation of tropical bagrid catfish (Mystus nemurus) spermatozoa; the effect of extender and cryoprotectant on the motility after short-term storage. Theriogenology, 62(1-2): 25-34. (2004)

[21] Idahor K. O., Yakubu A., Umar A. F., Yahaya F. and Musa L. A., Morphometric traits, spermatozoa microscopy and stripped eggs fertilization with milt collected from live African Mudfish (Clarias gariepinus). Livest. Res. Rural Dev. 2014; 26: 8. http://www.lrrd.org/lrrd26/8/idah26150.htm. (2014).

[22] Idahor K. O., Anatomical study of testes position in African Mudfish (Clarias gariepinus): guide to milt harvesting without sacrificing the fish. J. Anim. Prod. Adv., 3(9): 265-270. DOI:10.5455/ japa.20130919074634. (2013).

[23] Baldwin C. C., Collette B. B., Parenti L. R., Smith D. G. and Springer V. G., "Collecting fishes”. In: Lang M. A., Baldwin C. C. (Eds.) the Diving for Science "Methods and Techniques of Underwater Research". Proc. Ame. Acad. Underwater Sci. (Sixteenth annual Scientific Diving Symp. (1996).

Citation: Idahor K.O.et al., " Spermatozoa Revival with Addition of Diluted Dextrose Saline in African Catfish (Clarias gariepinus Burchell 1822)", International Journal of Research Studies in Zoology, vol. 4, no. 2, p. 7 11, 2018. http://dx.doi.org/10.20431/2454-941X.0402002

Copyright: (C) 2018 Authors. This is an open-access article distributed under the terms of the Creative Commons Attribution License, which permits unrestricted use, distribution, and reproduction in any medium, provided the original author and source are credited. 